\title{
ENERGY CONSUMED, WATER PRODUCTIVITY AND VITAMIN (C) CONCENTRATION OF ORANGE CROP UNDER DIFFERENT IRRIGATION SYSTEMS
}

\author{
Abousrie A. Farag*
}

ABSTRACT

Food and water consider the key to life. The aim of this study is to increase water productivity and enhancing the quality of the orange crop (Citrus sinensis Osbeck L.). To a chive that aim, four irrigation systems (conventional surface irrigation (SI), furrow irrigation (FI), surface drip irrigation (SDI) and subsurface drip irrigation (SSDI) under heavy soil (clay) at the north of delta Egypt. Soil water content (SWC), soil temperature and soil EC were measured during the growing season under irrigation systems. At the end of the growth season yield and vitamin $C$ were measured for three randomized samples for each treatment. Also, the energy consumed was estimated for each irrigation system. The results shown that the highest values of soil water content at depth $10 \mathrm{~cm}$ and along the distance of $200 \mathrm{~cm}$ from steam of tree were achieved under SSDI and SDI which increased SWC by $1.7 \%$ and $1.2 \%$ than SI, respectively and the lowest values of SWC was obtain at FI which decreased by $13.2 \%$ than SI, while, at depth $50 \mathrm{~cm}$ the highest values of SWC were under SI, applying FI, SSDI and SDI systems decreased the SWC by $16.9 \%, 14.7 \%$ and $7.3 \%$ than FI, respectively. At depth $100 \mathrm{~cm}$ the highest value of SWC was $31.9\left(\mathrm{~cm}^{3} \mathrm{~cm}^{3}\right)$ under FI. which increased by $40.2 \%$ than SI, followed by SSDI and SDI by values $27.9 \%$ and $7.7 \%$, respectively. Moreover, the results shown that, subsurface drip irrigation system (SSDI) gave the highest orange yield (6.1 $\left.\mathrm{Mg} \mathrm{fed}^{-1}\right)$, followed by the surface drip irrigation (SDI) system of $6 \mathrm{Mg} \mathrm{fed}^{-1}$, while the lowest yield was obtained under SI system $\left(5.2 \mathrm{Mg} \mathrm{fed}^{-1}\right)$. FI resulted in the higher yield compared with SI (5.4 $\left.M g \mathrm{fed}^{-1}\right)$ but at the same time, the lower yield as compared with both the SSDI and SDI systems. On the other hand, SSDI system increased the yield by $40.1 \%$, followed by SDI by $25.8 \%$ and FI by $8.6 \%$ than SI.

*Lecturer at Department of Agricultural and Biosystems Engineering, Faculty of Agriculture, Benha University, Egypt. abousrie.ahmad@fagr.bu.edu.eg 
The highest concentration of vitamin C was $23.4 \mathrm{mg} / 100 \mathrm{~g}$ under SSDI, followed by values 16.83 and 14.52 (mg/ $100 \mathrm{~g}$ ) under SDI and FI, respectively and the lowest concentration was 12.11 under SI. The highest value of consumptive energy was 1044.4 ( $\mathrm{kwh} / \mathrm{fed}$. season) achieved under SI, followed by 696.3 ( $k w h / f e d$. season) under FI and the lowest values were 613.1 and 642.3 ( $k w h / f e d$. season) under SSDI and SI, respectively.

KEYWORDS: Furrow irrigation, surface irrigation, drip irrigation, subsurface drip irrigation and soil water content.

\section{INTRODUCTION}

$\mathrm{W}$ ater and nutrients are the main resources for crops production. The food production will not meet the demands of population in Egypt according to the shortage of water (Mancosu, et. al, 2015) and the overpopulation on the other hand. In addition, the excessive use of fertilizers or nutrients will cause environmental problems beside of it requires expensive costs. Moreover, the increases of nutrients in contents of crops would cause potential hazard for human (Alfthan et al., 2015) and (Nganchamung and Robson, 2017).

Recently, the world pay attention not only for the yield but also for the contents and quality of crops. One of the most important crops in the world is citrus. It can be eating without cooking and it may be used in different products and manufactures of medicine. The most important content of citrus is vitamin $\mathrm{C}$. The increase of yield and quality of crop needs to use the appropriate amount of water and fertilizers.

The traditional surface irrigation system is the common irrigation system in Egypt and consumes more amount of water, while the pressurized irrigation systems play the main role in applying the water and nutrients by suitable amounts. The drip irrigation system is considered the more efficient irrigation system where its efficiency ranges from $90 \%$ to $95 \%$ (Slack, et. al, 2017).

The furrow irrigation is the most common method of surface irrigation. It is noted that in order to achieve uniform wetting of the soil water flow fed into the furrows is increased, while the excess water is collected at the end of the furrow, and then reset the bleed water collection network. The 
dependence of uniform wetting of the field on the length of the furrow, the water flow, soil fertility, and slope areas. Noticed, that the loss of water in the discharge of up to $40 \%$ of the irrigation norms, especially characteristic fields slope steeply. It is noticed that the loss of water in the discharge of up to $40 \%$ of the irrigation norms, especially characteristic for fields with steep slopes. Blow-off water washes away the fertile soil from fertilizers applied to improve soil fertility and crop yields. It is shown that as a result of irrigation erosion are reduced not only agricultural yields but also the quality of products (Manabaev, et. al, 2015).

The drip irrigation system is the frequent slow application of water onto the land surface or into the root-zone of crop. It can relieve low operating pressures problem at the end of the lateral lines (Mansour, 2013).

The subsurface drip irrigation (SSDI) system offer some advantages over other types of irrigation systems for specialty crop production, including water savings, improved trafficability, and a drier canopy (Steele, et. al, 1996). Also, subsurface drip irrigation offers many advantages for the management of water and nutrients (Camp, et. al, 1999). Subsurface drip irrigation system is a new technique of drip irrigation system and increasingly being used in agriculture in attempts to use the available water more efficiently (Kandelous, et. al, 2011). the drippers lied under soil surface by 15-30 cm for vegetable and $60 \mathrm{~cm}$ for trees (Slack, et. al, 2017). The aim of this research is to study the effects of irrigation systems on yield, water productivity (WP) and the concentration of vitamin $\mathrm{C}$ for the orange crop.

\section{MATERIAL AND METHODS}

Experimental site

The experimental field is located at Faculty of Agriculture, Benha University in the north of Egypt at latitude $31.223106 \mathrm{~N}$ longitude $30.357098 \mathrm{E}$ an altitude $15 \mathrm{~m}$ above sea level. The climate of this area is BWh (hot desert climates) according to Köppen climate classification (Köppen, 1936). The meteorological data were recorded by metrological station (iMatios), which constructed in the experimental site. The area of the experimental work was $2100 \mathrm{~m}^{2}$ and the distance between the rows of trees was $4 \mathrm{~m}$ and it was $5 \mathrm{~m}$ between trees at row. The age of orange trees 
was 15 years at the beginning of the experiment. It was irrigated by surface irrigation before the period of this experimental were (2017 - 2018).

Four soil samples were collected from depths of 0-30, 30-60, 60-90 and 90120 and analyzed laboratory according to Klute (1986) and Page et al. (1982). The soil properties were shown in Tables (1 and 2).

Table (1). Soil physical properties.

\begin{tabular}{|c|c|c|c|c|}
\hline \multirow[t]{2}{*}{ Property } & \multicolumn{4}{|c|}{ Soil depth $(\mathrm{cm})$} \\
\hline & $0-30$ & $30-60$ & $60-90$ & $90-120$ \\
\hline \multicolumn{5}{|l|}{ Particle size distribution } \\
\hline Corse Sand \% & 19.81 & 21.43 & 20.7 & 21.31 \\
\hline Fine sand $\%$ & 2.64 & 2.07 & 1.98 & 2.17 \\
\hline Silt $\%$ & 28.94 & 27.18 & 30.98 & 29.45 \\
\hline Clay \% & 48.61 & 49.32 & 46.34 & 47.07 \\
\hline Textural class & Clay & Clay & Clay & Clay \\
\hline Saturation percentage $\%$ & 70 & 79 & 78 & 80.1 \\
\hline Field capacity \% & 33.42 & 37.19 & 36.85 & 35.9 \\
\hline Welting point $\%$ & 15.8 & 17.98 & 18.04 & 18.23 \\
\hline Total available water, $\%$ TAW & 17.62 & 19.21 & 18.81 & 17.67 \\
\hline Bulk density $\left(\mathrm{Mg} \mathrm{m}^{-3}\right)$ & 1.11 & 1.13 & 1.19 & 1.12 \\
\hline Particle density $\left(\mathrm{Mg} \mathrm{m}^{-3}\right)$ & 2.14 & 2.3 & 2.2 & 2.16 \\
\hline Total porosity $\%$ & 49.12 & 50.1 & 45.61 & 46.21 \\
\hline
\end{tabular}

Table (2). Soil chemical properties.

\begin{tabular}{llllll}
\hline Property & \multicolumn{5}{c}{ Soil depth $(\mathrm{cm})$} \\
\cline { 2 - 6 } $\mathrm{pH}$ & & $0-30$ & $30-60$ & $60-90$ & $90-120$ \\
EC. $\left(\mathrm{dS} \mathrm{m}^{-1}\right)$ & & 7.12 & 7.83 & 8.04 & 8.39 \\
& & 3.54 & 3.43 & 3.8 & 2.2 \\
\cline { 2 - 6 } Cations $\left(\mathrm{mmol} \mathrm{l}^{-1}\right)$ & $\mathrm{Na}^{+}$ & 22.0 & 15.1 & 20.0 & 15.9 \\
& $\mathrm{~K}^{+}$ & 0.7 & 0.6 & 0.7 & 0.6 \\
& $\mathrm{Ca}^{++}$ & 6.5 & 5.0 & 7.1 & 6.0 \\
& $\mathrm{Mg}^{++}$ & 3.0 & 2.1 & 5.0 & 6.5 \\
\hline $\mathrm{CI}^{-}$ & 20.0 & 15.8 & 23.0 & 19.0 \\
& $\mathrm{CO}_{3}^{--}$ & 5.0 & 5.0 & 5.1 & 7.7 \\
Total nitrogen $\left(\mathrm{mmol} \mathrm{l}^{-1}\right)$ & $\mathrm{HCO}^{-}$ & 9.0 & 10.9 & 9.0 & 8.9 \\
Available K $\left(\mathrm{mg} \mathrm{kg}^{-1}\right)$ & $\mathrm{SO}^{--}$ & 1.8 & 8.9 & 4.3 & 6.6 \\
Available P $\left(\mathrm{mg} \mathrm{kg}^{-1}\right)$ & & 0.12 & 0.11 & 0.07 & 0.09 \\
& & 401.3 & 386.7 & 374.5 & 365.3 \\
\hline
\end{tabular}




\section{Irrigation systems}

The area of the experiment was divided into 4 equal parts. Four irrigation systems i.e. conventional surface irrigation (SI), furrow irrigation (FI), surface drip irrigation (SDI) and subsurface drip irrigation (SSDI) systems were used for irrigating the orange crop during the period from 2017 until 2018. The specifications of the drip irrigation system were: the emitters were inline $8\left(1 \mathrm{~h}^{-1}\right)$ discharge at 0.8 bar and the number of emitters per tree was 4 . The lateral lines under subsurface drip irrigation system were lied under soil surface by $60 \mathrm{~cm}$ according to Slack, et. al, (2017).

\section{Irrigation schedule}

Evapotranspiration was estimated by Benman-Monteith equation and crop factor was selected from FAO Tables according to Allen (2008). Total Available Water (TAW) is the water content at field capacity minus the water content at wilting point multiplied by root depth and a specific gravity of soil as shown in Table (1). The applied irrigation depth was estimated by dividing the TAW by the efficiency of the irrigation system and leaching requirements. The assumed values for efficiency for SI, FI, SDI, and SSDI were $60 \%, 70 \%, 90 \%$, and $95 \%$, respectively. The estimated leaching requirement according to (Rhoades, 1974).

\section{Measuring of soil water content, soil EC and soil temperature}

Four soil profiles under trees, $50 \mathrm{~cm}$ width, $200 \mathrm{~cm}$ long and $100 \mathrm{~cm}$ depth were done for each irrigation system. 6 points and 9 layers (depths of 10 , $20,30,40,50,60,70,80 \mathrm{~cm}$ ) were selected for measuring the soil water content as shown in Figures (1, 3 and 5).

Ten locations in the distance between rows of trees were been selected $(0$, , 25, 50, 75, 100, 150, 200, 300, 400 and $500 \mathrm{~cm}$ ) away from tree at depths of 10, 50 and $100 \mathrm{~cm}$ of soil surface, for measuring SWC, soil EC and soil temperature were measured by wet sensor and $\mathrm{HH} 2$ device three times during the growing season. Surfer 15 and OrgingLab 9 programs were used for drawing and analyzing the data as shown in Figures (9, 10 and 11).

\section{Yield and water productivity}

The crop was harvested at full maturity stage for all replicates ( 3 trees) of each treatment. The water productivity is the yield $\left(\mathrm{kg} \mathrm{fed}^{-1}\right)$ divided by the total water $\left(\mathrm{m}^{3} \mathrm{fed}^{-1}\right)$ (Molden et. al., 2010) and (Farag, 2018). 


\section{Energy consumed}

The used electrical motors were $3 \mathrm{~kW}$ under drip irrigation system (SDI and SSDI) and $15 \mathrm{~kW}$ under surface irrigation systems (SI and FI). The consumptive energy was estimated by multiplying the number of operating hours by electrical consumed energy in hour $(\mathrm{kWh})$. The average price of electrical energy for each $1 \mathrm{kWh}$ during the period of the experiment was 0.75 Egyptian pound during the experimental period.

\section{Statistical analysis}

The experimental design was a randomized complete block design (RCBD) with 3 replicates. The results of yield, water productivity and Vitamin C concentration of orange were analyzed by using ANOVA one way to show the differences between the treatments at sig. 0.05. The SPSS program version number 25 was used for carrying out this analysis.

\section{RESULTS AND DISCUSSION}

\section{I.Soil water distribution under the studded irrigation systems}

\section{I.1 Surface irrigation system}

Data in Figures ( 1 and 2) show the soil water distribution in different layers of soil profile under surface irrigation system.

The SWC increased in the vertical direction from $24.4\left(\mathrm{~cm}^{3} \mathrm{~cm}^{-3}\right)$ at the soil surface to $42.83\left(\mathrm{~cm}^{3} \mathrm{~cm}^{-3}\right)$ at a depth of $80 \mathrm{~cm}$. The SWC at the surface increased with the distance from the tree to $45 \mathrm{~cm}\left(30.8 \mathrm{~cm}^{3} \mathrm{~cm}^{-3}\right)$ beyond which it decreased to $25.9\left(\mathrm{~cm}^{3} \mathrm{~cm}^{-3}\right)$ at $200 \mathrm{~cm}$ from the tree. SWC increased from 34 and $38.7\left(\mathrm{~cm}^{3} \mathrm{~cm}^{-3}\right)$ near the tree to 37 and $40.4\left(\mathrm{~cm}^{3}\right.$ $\mathrm{cm}^{-3}$ ) at depths of 20 and $30 \mathrm{~cm}$ at distance of $80 \mathrm{~cm}$ from tree. Within the depth of $40 \mathrm{~cm}$ to $80 \mathrm{~cm}$, the changes in soil water content were very small and the soil water content increased in a horizontal direction away of the tree. Where d 10, d 20, d 40, d 60 and d 80 are the depths of soil layers at $10,20,40,60$ and $80 \mathrm{~cm}$.

\section{I.2 Furrow irrigation system}

Data in Figures (3 and 4) show the soil water distribution in different layers of soil profile under furrow irrigation system. The SWC increased from $25.48\left(\mathrm{~cm}^{3} \mathrm{~cm}^{-3}\right)$ at the surface to $40.9\left(\mathrm{~cm}^{3} \mathrm{~cm}^{-3}\right)$ at a depth of $80 \mathrm{~cm}$, the percentage of increase in soil water content with the depth decreased with increasing the depth from surface to $80 \mathrm{~cm}$ depth. The difference in SWC 
between the upper layers were about 10.35 and 4.27 and at lower layers 0.83 and $-0.05\left(\mathrm{~cm}^{3} \mathrm{~cm}^{-3}\right)$. SWC increased in the horizontal direction from tree to the next tree on the row. On the other hand, SWC increased in the horizontal direction from tree at depths of $0,30,40,50,60$, and $70 \mathrm{~cm}$ from soil surface but it decreased at depths of 10,20 and $80 \mathrm{~cm}$ from the soil surface as shown in Fig. (3 and 4).

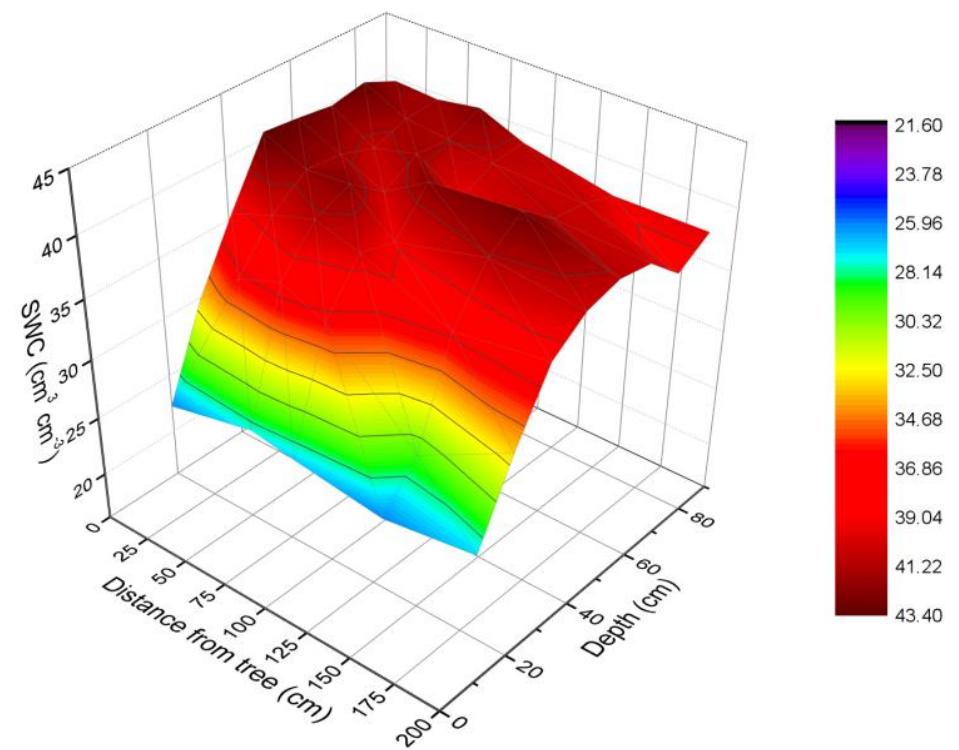

Fig. (1). The soil water content distribution under surface irrigation system.

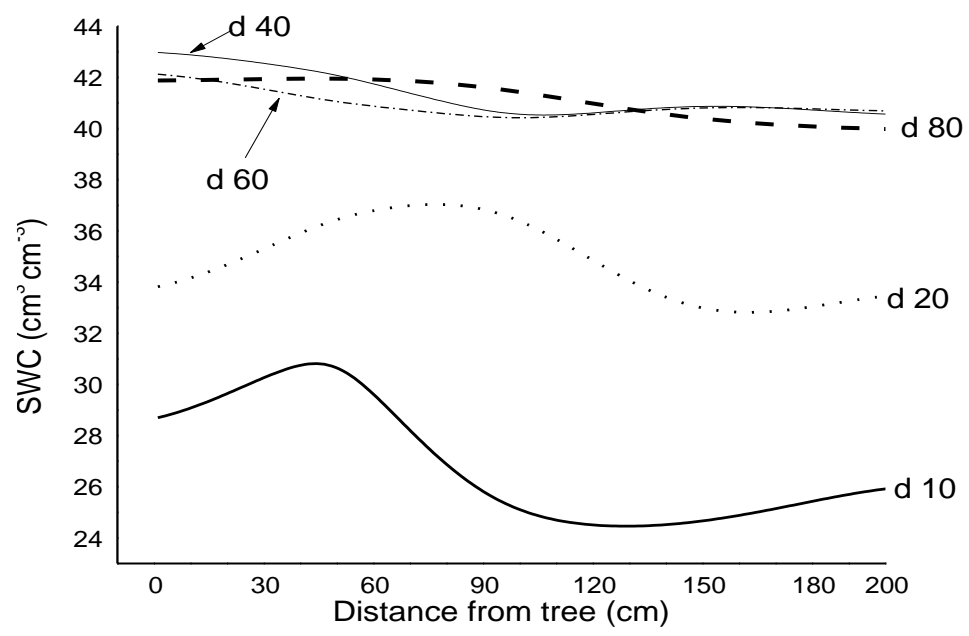

Fig. (2). The changes in soil water content at different depths for a radial distance of $200 \mathrm{~cm}$ from the tree under surface irrigation. 


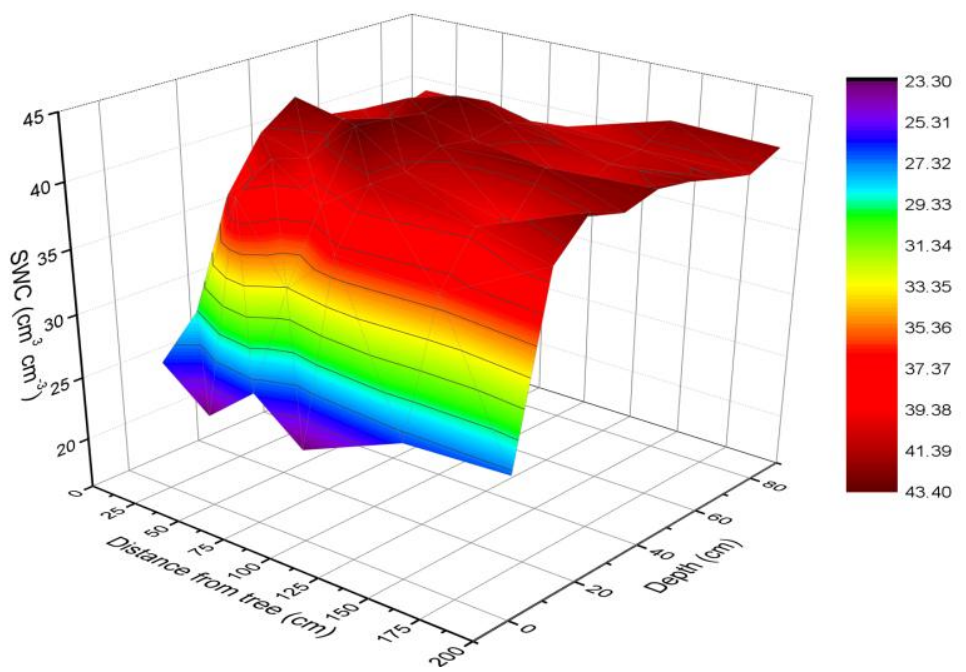

Fig. (3). The soil water content distribution under furrow irrigation system.

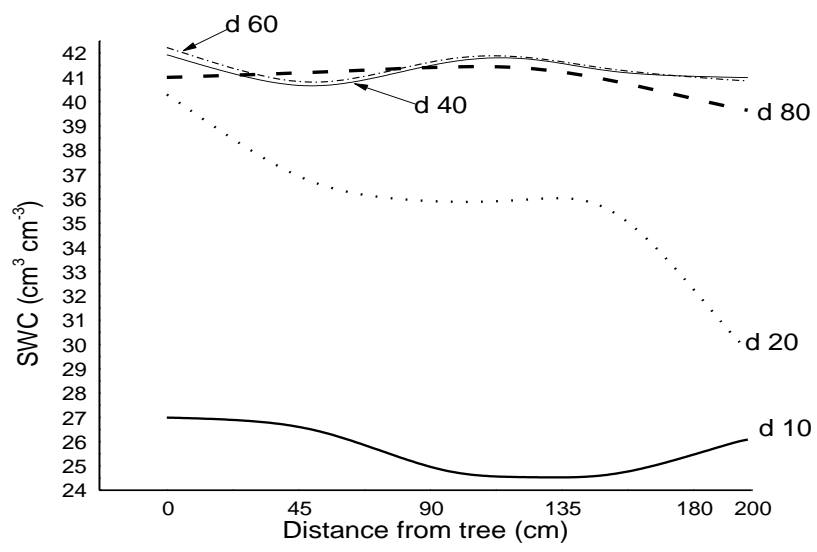

Fig. (4). The changes in soil water content at different depths for radial distance $200 \mathrm{~cm}$ from tree under furrow irrigation system.

SWC increased in the vertical direction from $24.5\left(\mathrm{~cm}^{3} \mathrm{~cm}^{-3}\right)$ at surface to $42.83\left(\mathrm{~cm}^{3} \mathrm{~cm}^{-3}\right)$ at a depth of $80 \mathrm{~cm}$. SWC gradually decreased with the distance from tree up to $200 \mathrm{~cm}$. SWC decreased from 27 and 41 $\left(\mathrm{cm}^{3} \mathrm{~cm}^{-3}\right)$ near the tree to 26 and $29.8\left(\mathrm{~cm}^{3} \mathrm{~cm}^{-3}\right)$ at a distance of $200 \mathrm{~cm}$ from tree at soil surface and $20 \mathrm{~cm}$ depth, respectively. Within the depth of $40 \mathrm{~cm}$ to $80 \mathrm{~cm}$ the changes in SWC were very small and it decreased in horizontal direction away of tree as shown in Figures (3 and 4).

\section{I.3 Surface drip irrigation}

The data in Figures (5 and 6) show the soil water distribution in different layers of soil profile under surface drip irrigation system. The SWC 
increased in the vertical direction from $26.25\left(\mathrm{~cm}^{3} \mathrm{~cm}^{-3}\right)$ at surface to 41.7 $\left(\mathrm{cm}^{3} \mathrm{~cm}^{-3}\right)$ at a depth of $80 \mathrm{~cm}$. The SWC at surface increased from 26.75 $\left(\mathrm{cm}^{3} \mathrm{~cm}^{-3}\right)$ near tree to $31.8\left(\mathrm{~cm}^{3} \mathrm{~cm}^{-3}\right)$ at horizontal distance of $60 \mathrm{~cm}$ thereafter it decreased to $25.7\left(\mathrm{~cm}^{3} \mathrm{~cm}^{-3}\right)$ at a $150 \mathrm{~cm}$ distance beyond witch it gradually increased to $26.4\left(\mathrm{~cm}^{3} \mathrm{~cm}^{-3}\right)$ at distance of $200 \mathrm{~cm}$ from tree. The SWC increased from 34 and $38.7\left(\mathrm{~cm}^{3} \mathrm{~cm}^{-3}\right)$ near the tree to 37 and $40.4\left(\mathrm{~cm}^{3} \mathrm{~cm}^{-3}\right)$ at a distance of $80 \mathrm{~cm}$ at the depths 20 and $30 \mathrm{~cm}$, respectively. Within the depth of $40 \mathrm{~cm}$ to $80 \mathrm{~cm}$ the changes in SWC were very small and it increased in horizontal direction away from the tree as shown in Figures (5 and 6).

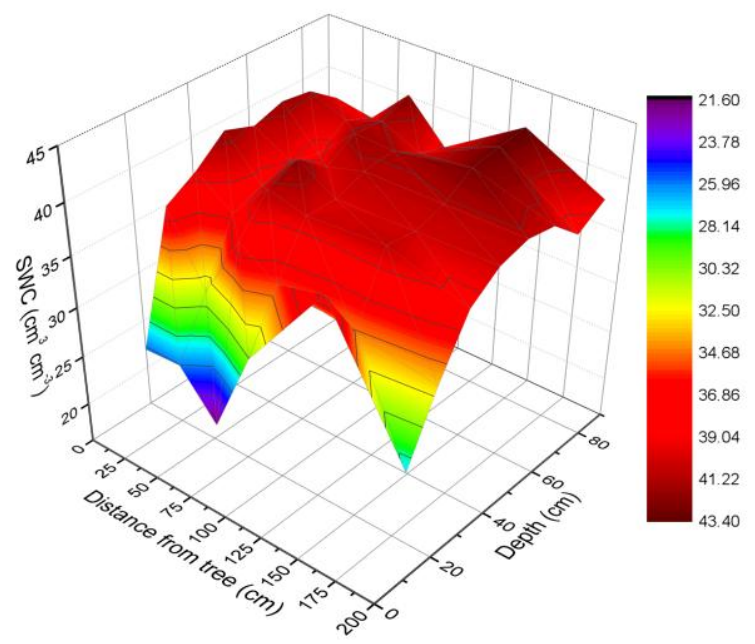

Fig. (5). The soil water content distribution under surface drip irrigation system.

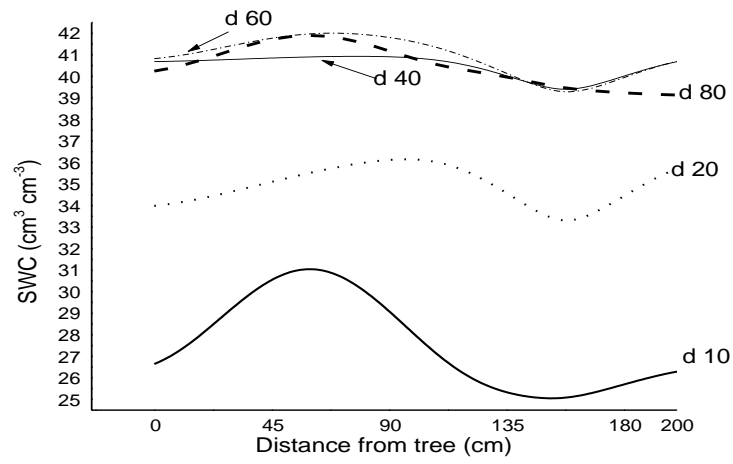

Fig.(6). The changes in soil water content at different depths for radial distance $200 \mathrm{~cm}$ from tree under surface drip irrigation system. 


\section{I.4 Subsurface drip irrigation}

The data in Figures ( 7 and 8 ) show the soil water distribution in different layers of soil profile under subsurface drip irrigation system.

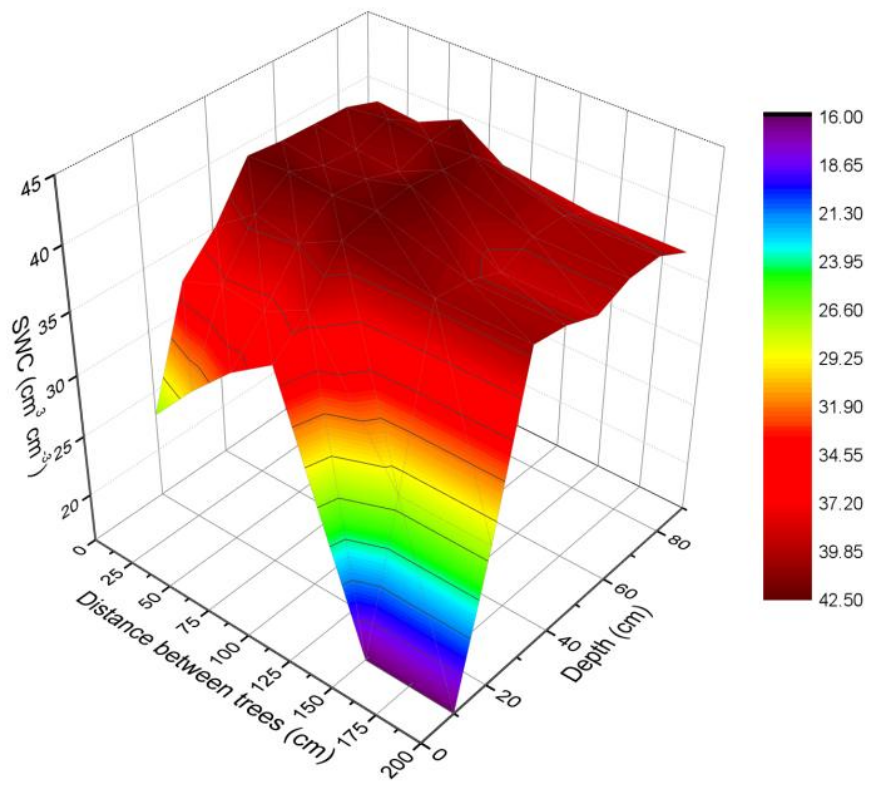

Fig. (7). The soil water content distribution under subsurface drip irrigation system.

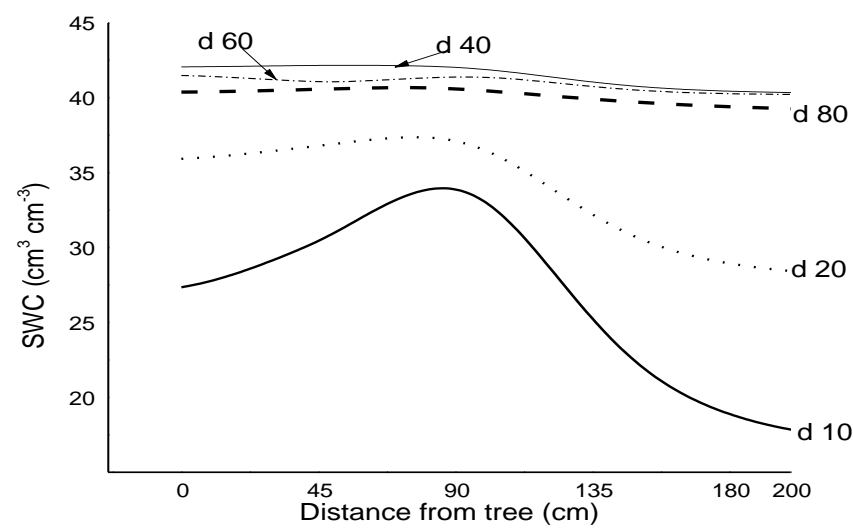

Fig.(8). The changes in soil water content at different depths for radial

distance $200 \mathrm{~cm}$ from tree under subsurface drip irrigation system.

The SWC increased from 27.02 at soil surface to $40.84 \pm 0.47\left(\mathrm{~cm}^{3} \mathrm{~cm}^{-3}\right)$. SWC decreased in the radial direction away from tree. The mean values of 
SWC in the distance from tree to $200 \mathrm{~cm}$ for the upper layers were \pm 5.4 and $\pm 3.32\left(\mathrm{~cm}^{3} \mathrm{~cm}^{-3}\right)$ at depths of 10 and $20 \mathrm{~cm}$ respectively, that were higher than the changes at the lower soil layers, that ranged from 0.49 to $0.85\left(\mathrm{~cm}^{3} \mathrm{~cm}^{-3}\right)$ at depths of 30 to $80 \mathrm{~cm}$, respectively.

\section{II.Relationship among SWC, soil electrical conductivity $\left(\mathrm{EC}_{\text {soil }}\right)$ and soil temperature ( $\left.T_{\text {soil }}\right)$ under different soil depths}

The results of average changes of $\mathrm{SWC}, \mathrm{EC}_{\text {soil }}$ and $\mathrm{T}_{\text {soil }}$ along the distance between rows of trees $(500 \mathrm{~cm})$ before irrigation at depths of 10, 50 and $100 \mathrm{~cm}$ of soil surface are shown in Figures. (9,10 and 11).
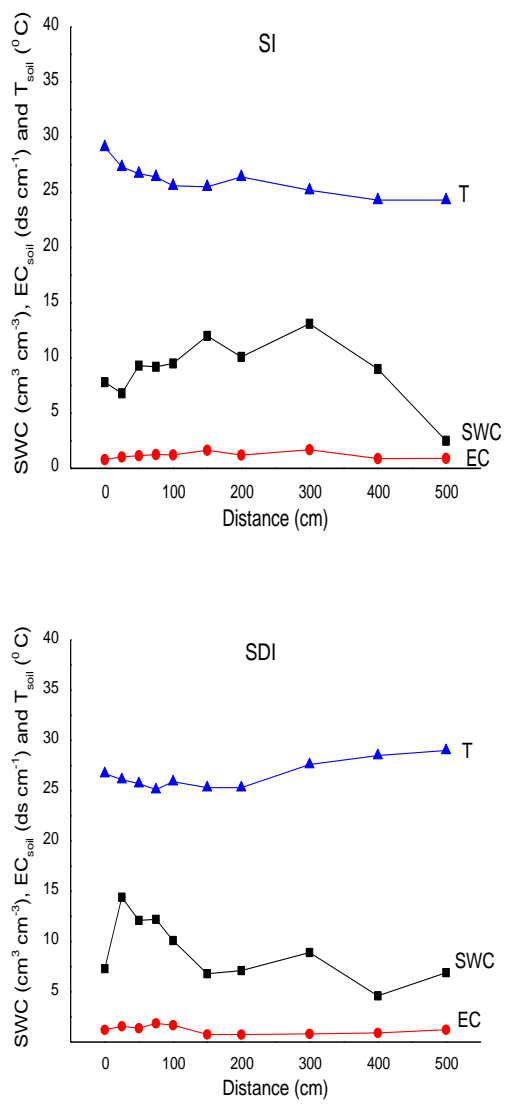
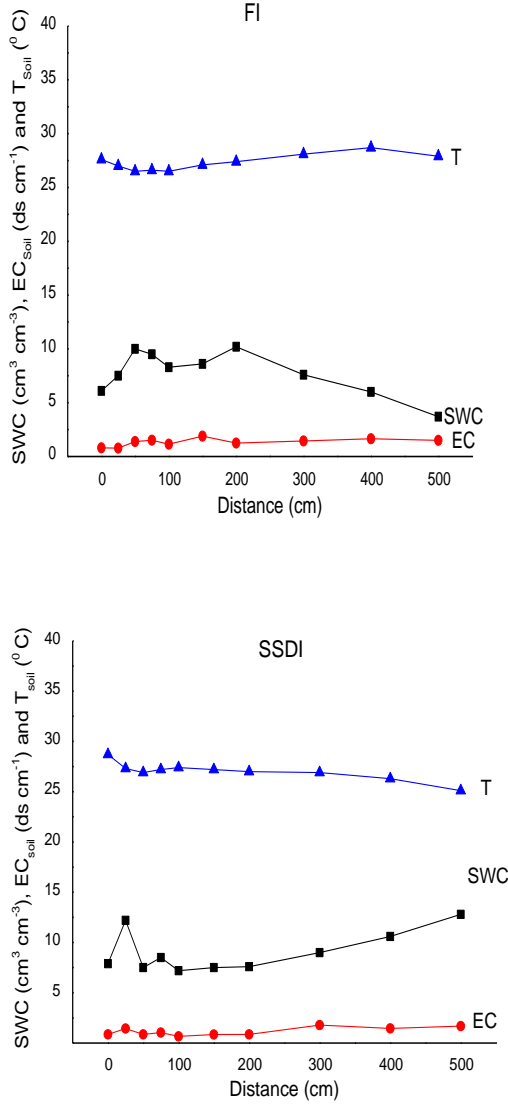

Fig. (9). The changes in SWC, soil EC and soil temperature under different irrigation systems at a depth of $10 \mathrm{~cm}$ from soil surface.

The results show that the highest values of SWC at depth $10 \mathrm{~cm}$ and along the distance of $200 \mathrm{~cm}$ from steam of tree were achieved under SSDI and 
SDI which increased SWC by $1.7 \%$ and $1.2 \%$ than SI, respectively and the lowest values of SWC was obtain at FI which decreased by $13.2 \%$ than SI, while, at depth $50 \mathrm{~cm}$ the highest values of SWC were under SI, applying FI, SSDI and SDI systems decreased the SWC by $16.9 \%, 14.7 \%$ and $7.3 \%$ than FI, respectively. At depth $100 \mathrm{~cm}$ the highest value of SWC was $31.9\left(\mathrm{~cm}^{3} \mathrm{~cm}^{3}\right)$ under FI، which increased by $40.2 \%$ than SI, followed by SSDI and SDI by values $27.9 \%$ and $7.7 \%$, respectively. Generally, the increase in SWC was associated with increase in soil EC which means that, increasing soil EC is duo to the increase of EC of irrigation water as shown in Figures (9, 10 and 11).
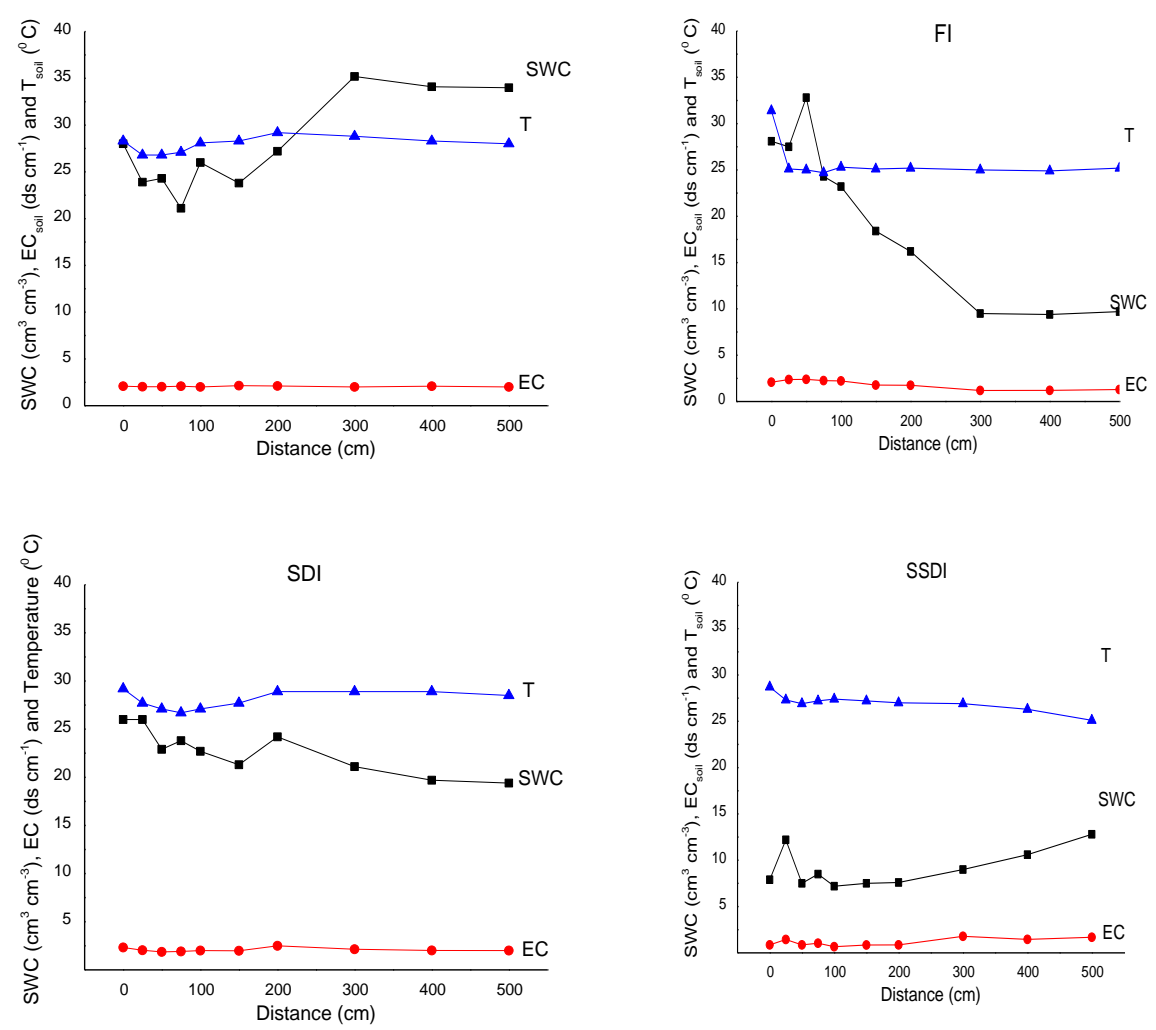

Fig. (10). The changes in SWC, soil EC and soil temperature under different irrigation systems at a depth of $50 \mathrm{~cm}$ from soil surface.

\section{Irrigation water applied}

The total applied irrigation water for each treatment is shown in Table (3). 
Table (3). The applied irrigation water, WR

\begin{tabular}{|l|c|c|c|c|c|}
\hline Irrigation water applied & season & SDI & SSDI & FI & SI \\
\hline \multirow{2}{*}{ WR $\left(\mathrm{m}^{3} /\right.$ fed season $)$} & 2017 & 1414.4 & 1350.1 & 2333.3 & 3500.0 \\
\cline { 2 - 7 } & 2018 & 1478.44 & 1411.24 & 2333.33 & 3500.00 \\
\hline \multirow{2}{*}{ WR $\left(\mathrm{m}^{3} /\right.$ tree season $)$} & 2017 & 6.7 & 6.4 & 11.1 & 16.7 \\
\cline { 2 - 7 } & 2018 & 7.04 & 6.72 & 11.11 & 16.67 \\
\hline
\end{tabular}
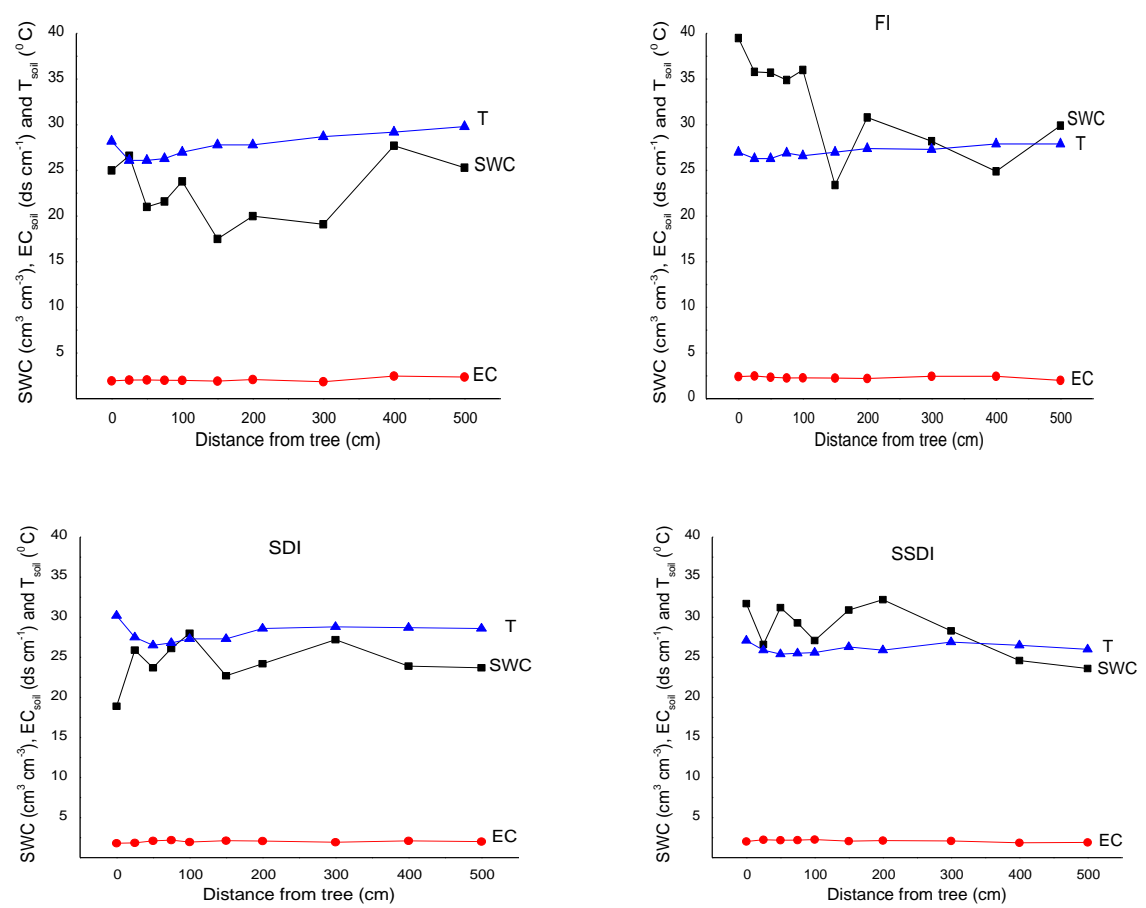

Fig. (11). The changes in SWC, soil EC and soil temperature under different irrigation systems at a depth of $100 \mathrm{~cm}$ from soil surface.

\section{Orange yield, and water productivity}

The results of orange yield, water applied, water productivity and consumptive energy during the seasons 2017 and 2018 are shown in Table (4). The results show that, the average fruit yield differed significantly among the four irrigation systems. The highest orange yield was achieved under SSDI system $\left(6.1 \mathrm{Mg}\right.$. fed $\left.{ }^{-1}\right)$ followed by SDI system $\left(6 \mathrm{Mg} \mathrm{fed}^{-1}\right)$ while the lowest yield was obtained under the SI system $\left(5.2 \mathrm{Mg} \mathrm{fed}^{-1}\right)$. The FI resulted in higher yield compared with the SI system $\left(5.4 \mathrm{Mg} \mathrm{fed}^{-1}\right)$ but at the same time, lower yield as compared with both SDI and SSDI systems. On the other hand, SSDI system increased the yield by $40.1 \%$, followed by SDI by $25.8 \%$ and FI by $8.6 \%$ as compared with SI. 
Table (4). Yield, applied irrigation water and water productivity (WP) of the studied irrigation systems.

\begin{tabular}{|l|c|c|c|c|}
\hline \multirow{2}{*}{$\begin{array}{l}\text { Irrigation } \\
\text { systems }\end{array}$} & \multicolumn{2}{|c|}{ Yield $\left(\mathrm{Mg} \mathrm{fed}^{-1}\right)$} & \multicolumn{2}{c|}{$\mathrm{WP}\left(\mathrm{kg} \mathrm{m}^{-3}\right)$} \\
\cline { 2 - 5 } SDI & 2017 & 2018 & 2017 & 2018 \\
\hline SSDI & 4.96 & 6.97 & 3.1 & 4.7 \\
\hline FI & 5.18 & 7.11 & 3.9 & 3.7 \\
\hline SI & 5.20 & 5.54 & 1.7 & 2.4 \\
\hline
\end{tabular}

Moreover, the results show that the SSDI saved the applied irrigation water (60.5\%), followed by SDI (59 \%) and FI (33\%) as compared with SI system.

The highest values of WP were found under SDI $\left(3.9 \mathrm{~kg} \mathrm{~m}^{-3}\right)$ followed by SSDI $\left(3.8 \mathrm{~kg} \mathrm{~m}^{-3}\right)$, while, the lowest WP values were 2.05 and $1.3\left(\mathrm{~kg} \mathrm{~m}^{-3}\right)$ under FI and SI systems, respectively. Moreover, the water productivity of orange crop under SSDI increased by $200 \%$, followed by SDI (192.3\%) and FI (57.7 \%) as compared with SI system.

\section{Vitamin $\mathbf{C}$ concentration}

The results of vitamin $\mathrm{C}$ concentration in orange trees was shown in Fig. (12). The highest concentration of vitamin $C$ was $23.41(\mathrm{mg} / 100 \mathrm{~g})$ under SSDI, followed by SDI (16.83 mg/ 100g) and FI (14.52 mg/ 100g) and the lowest value was 12.11 under SI system.

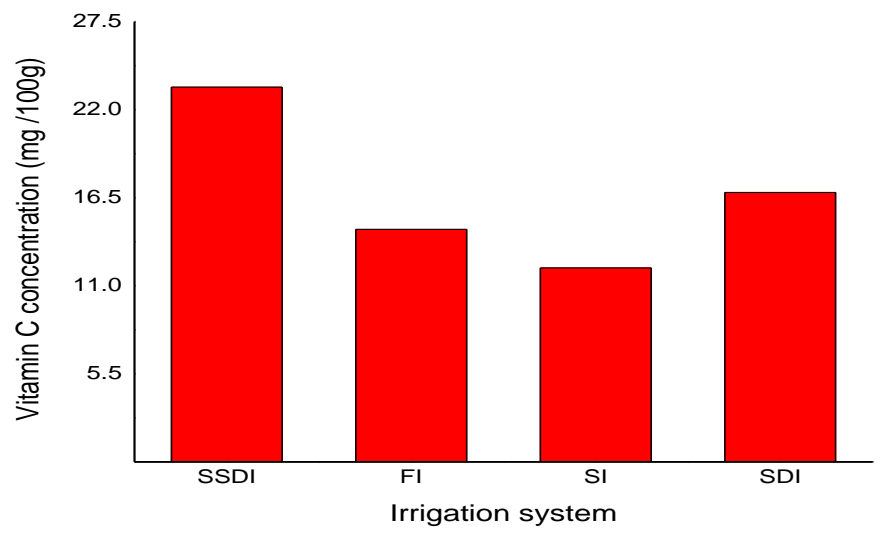

Fig.(12).Vitamin C concentration in orange fruits.

\section{Consumptive energy}

The energy consumed during the seasons of 2017 and 2018 are shown in Table (5). The using of SSDI decreased the consumptive energy by $41.3 \%$, followed by SDI (38.45 \%) and FI (33.15\%) as compared with SI system. 
The highest value of consumptive energy was 1305.5 (kWh / fed. season) achieved under SI, followed by 870.3 (kWh /fed. season) under FI and the lowest values were 766.35 and 802.85 (kWh/ fed. season) under SSDI and SDI, respectively.

Table (5). Energy consumed and water productivity of the different irrigation systems.

\begin{tabular}{|c|c|c|c|c|c|c|c|c|}
\hline $\begin{array}{c}\text { Irrigation } \\
\text { system }\end{array}$ & \multicolumn{2}{|c|}{$\begin{array}{c}\text { Consumed } \\
\text { energy }(\mathrm{kWh})\end{array}$} & \multicolumn{2}{c|}{$\begin{array}{c}\text { Total consumed } \\
\text { Energy } \\
(\mathrm{kWh} / \mathrm{fed} . \mathrm{seas} n)\end{array}$} & \multicolumn{2}{|c|}{ Total cost (LE /fed) } & \multicolumn{2}{c|}{$\begin{array}{c}\text { Energy } \\
\text { saving (\%) }\end{array}$} \\
\hline Year & 2017 & 2018 & 2017 & 2018 & 2017 & 2018 & 2017 & 2018 \\
\hline SDI & 3.73 & 3.73 & 785.1 & 820.6 & 588.8 & 615.5 & 39.9 & 37 \\
\hline SSDI & 3.73 & 3.73 & 749.4 & 783.3 & 562.0 & 587.5 & 42.6 & 40 \\
\hline FI & 18.65 & 18.65 & 870.3 & 870.3 & 652.8 & 652.8 & 33.3 & 33 \\
\hline SI & 18.65 & 18.65 & 1305.5 & 1305.5 & 979.1 & 979.1 & 0 & 0 \\
\hline
\end{tabular}

\section{CONCLUSION}

The soil water content distribution in soil, differed according to the irrigation system. SSDI and SDI achieved the highest values of SWC at a depth of $10 \mathrm{~cm}$ from soil surface, while, at a depth of $50 \mathrm{~cm}$ SI and FI systems gave the highest values of SWC. At a depth of $100 \mathrm{~cm}$ FI system achieved the highest value of SWC. The results of yield show that, subsurface drip irrigation system (SSDI) gives the highest orange yield, followed by the surface drip irrigation (SDI) system, while the lowest yield was obtained under SI system. FI resulted in the higher yield compared with SI system. The highest concentration of vitamin C was under SSDI, followed by values SDI and FI systems, respectively and the lowest concentration of vitamin $\mathrm{C}$ was under SI system. The SWC at nearest the soil surface was more effect on yield and vitamin (C) concentration. The using of SSDI decreased not only the consumptive energy by $41.3 \%$, followed by SDI (38.45 \%) and FI (33.15 \%) as compared with SI system but also saved the applied irrigation water (60.5\%), followed by SDI (59 $\%)$ and FI (33\%) as compared with SI system.

\section{ACKNOWLEDGMENT}

The author thanks ASRT and ERANETMED "is funded by the European Commission's 7th Framework Program" for supporting this study, which carried out under the project of "Water Saving in Agriculture: technological developments for the sustainable management of limited water resources in the Mediterranean area". 


\section{REFERENCES}

Alfthan, G., Eurola, M., Ekholm, P., Venalainen, E. R., Root, T., Korkalainen, K., Selenium Working, G. (2015). Effects of nationwide addition of selenium to fertilizers on foods, and animal and human health in Finland: From deficiency to optimal selenium status of the population. J Trace Elem Med Biol, 31, 142-147. doi:10.1016/j.jtemb.2014.04.009

Camp, C. R., Bauer, P. J., \& Busscher, W. J. (1999). Evaluation of notillage crop production with subsurface drip irrigation on soils with compacted layers. Transactions of the ASABE, 42(4), 911-917. Retrieved 7 14, 2019, doi: 10.13031/2013.13271

Farag, A. (2018). Irrigation management of pepper crop under surface and sub-surface drip irrigation systems by using expert system, IRRMET and CropWat. Misr J. Ag. Eng., 35 (4): 1293 - 1308

Kandelous, M. M., Šimůnek, J., Genuchten, M. v., and Malek, K. (2011). Soil water content distributions between two emitters of a subsurface drip irrigation system. Soil Science Society of America Journal, 75(2), 488-497. Retrieved 7 5, 2019, doi:10.2136/sssaj2010.0181

Köppen, W. (1936). Das geographische System der Klimate, in: Handbuch der Klimatologie, Band 1, Teil C., edited by: Köppen, W. and Geiger, R., Gebr. Borntraeger, Berlin, 1-44, 1936.

Manabaev, N. T., Aubakirova, F. H., Kenzhibaeva, G. S., Zhumabaeva, R. O., \& Assylbekov, B. Z. (2015). Improved Technology of Furrow Irrigation on Mountain Slope Fields. The Journal of Agricultural Science, 7(9), 182. Retrieved 7 14, 2019, doi:10.5539/jas.v7n9p182

Mancosu, N., Snyder, R., Kyriakakis, G., \& Spano, D. (2015). Water Scarcity and Future Challenges for Food Production. Water, 7(12), 975-992. doi:10.3390/w7030975

Mansour, H. (2013). Evaluation Of Closed Circuits Drip Irrigation By Using Simulation Program Under Automation Controller. Journal of Automation and Control Engineering, 2(3). Retrieved 7 14, 2019, from http://seipub.org/ijace/download.aspx?id=2740

Molden D, Oweis T, Steduto P, Bindraban P, Hanjra MA and Kijne J (2010). Improving agricultural water productivity: Between optimism and caution. Agric Water Manage 97: 528-535. 
Nganchamung, T., \& Robson, M. (2017). Chemical fertilizer use and acute health effects among chili farmers in Ubon Ratchathani Province, Thailand (Vol. 31). Doi: 10.14456/jhr.2017.53

Slack, D. C., Esteves, R. R., Espejel, A., Oyorsaval, B., \& Ma, Y. (2017).

Subsurface drip irrigation: A technology for safer irrigation of vegetable crops. Engineering and Applied Science Research, 44(2), 111-114. Doi.org/10.14456/easr.2017.16

Steele, D. D., Greenland, R. G., \& Gregor, B. L. (1996). Subsurface Drip Irrigation Systems for Specialty Crop Production in North Dakota. Applied Engineering in Agriculture, 12(6), 671-679. Doi: $10.13031 / 2013.25697$

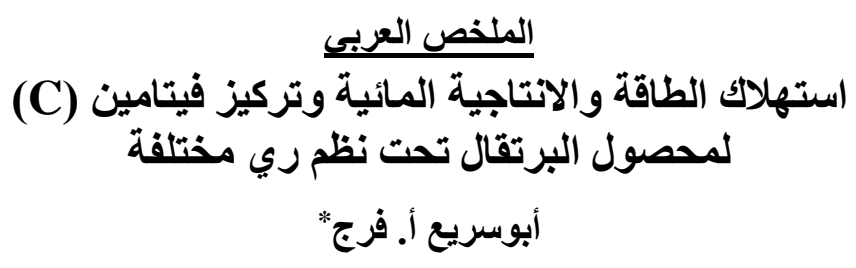

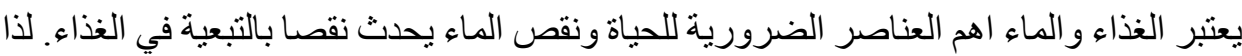

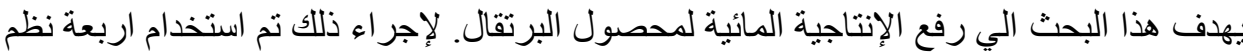

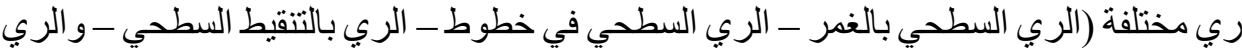

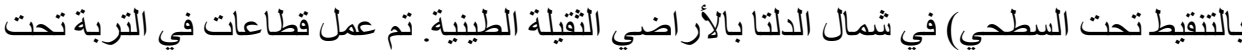

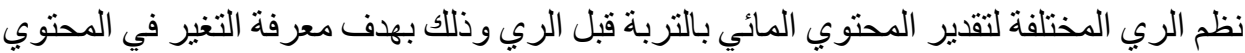

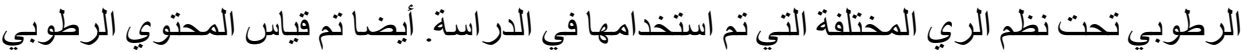

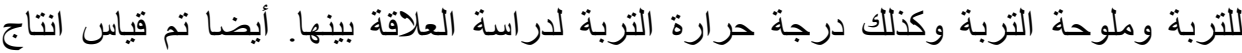

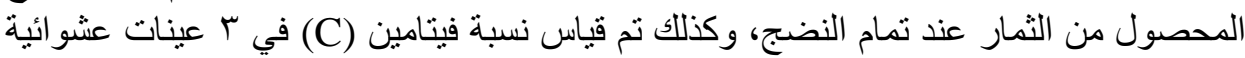

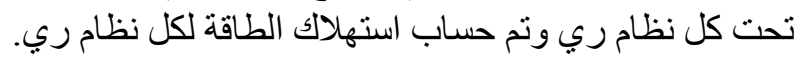

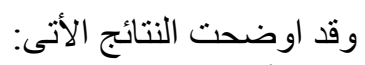

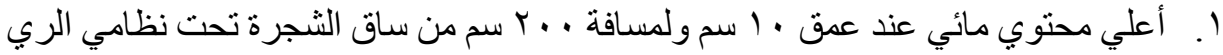

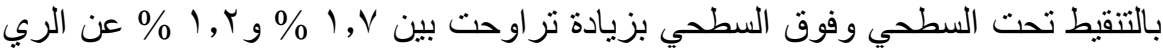

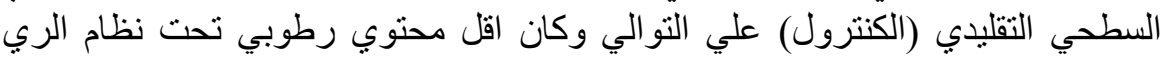

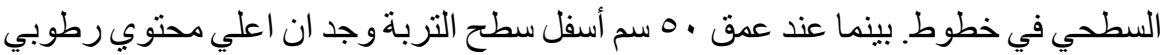

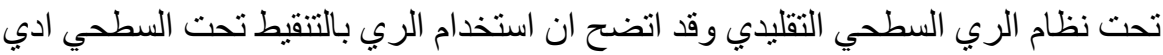

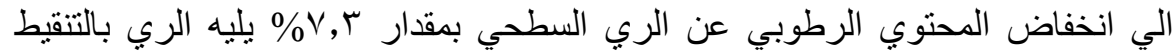

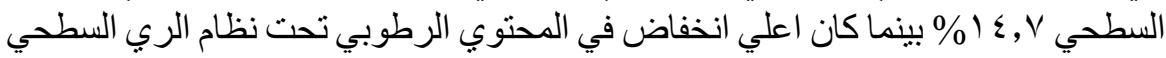

$$
\text { في خطوط (7, (7) (\%). }
$$

*مدرس هندسة النظم الزراعية والحيوية بكلية الزراعة جامعة بنها 


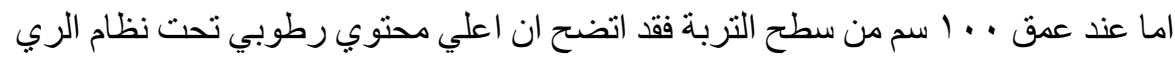

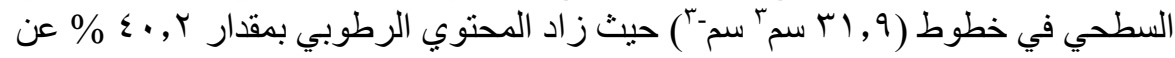

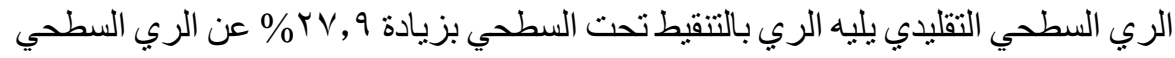

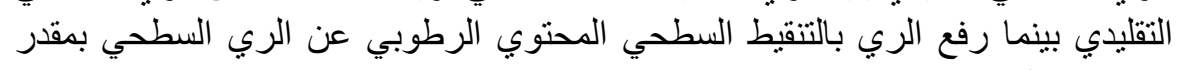
\% $\%$ \%, $\vee$

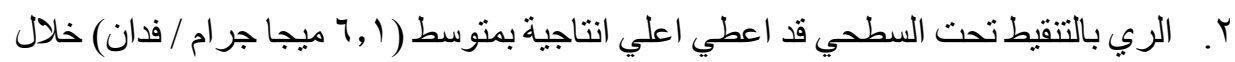

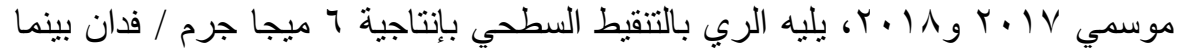

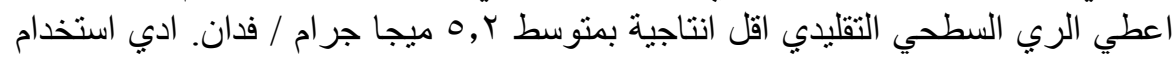

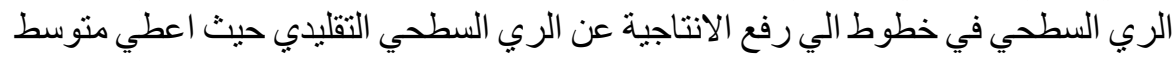

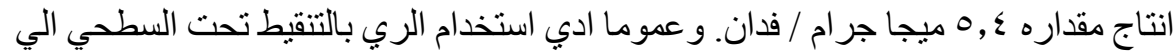

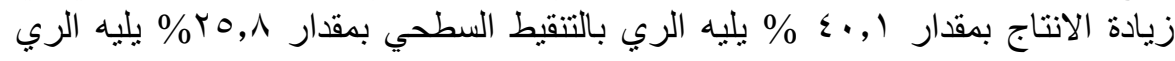

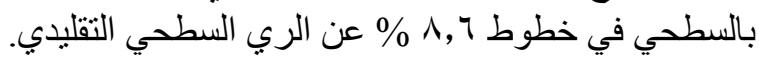

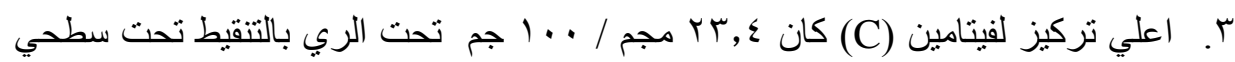

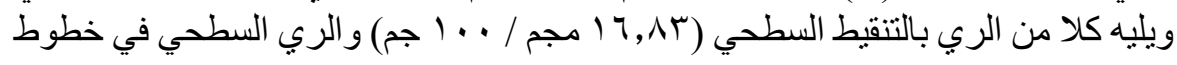

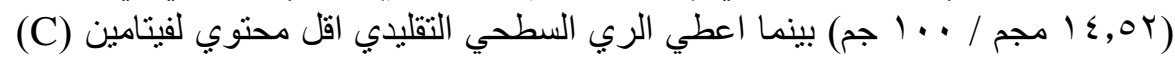

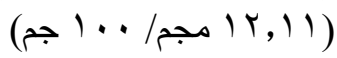

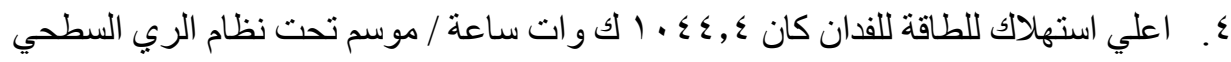

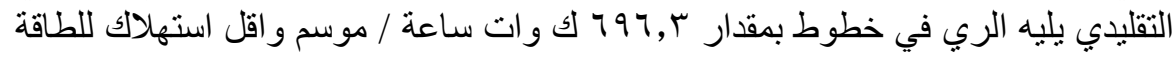

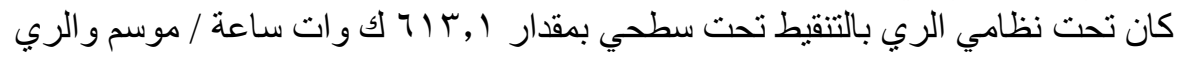

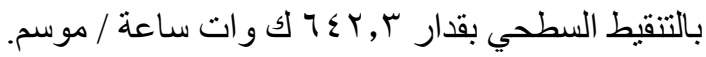

